\title{
Administrative Efficiency of Environmental Protection Funds in Poland in the Years 2006-2019
}

\author{
Krzysztof Berbeka*, Marek Bugdol \\ Faculty of Management and Social Communication, Institute of Economics, Finance and Management, \\ Jagiellonian University in Cracow, Poland
}

Received: 6 May 2021

Accepted: 28 June 2021

\begin{abstract}
The objective of this paper was to determine the administrative efficiency of environmental protection funds in Poland in the years 2006-2019. The basic research method applied in the empirical part was an analysis of data contained in the documentation of environmental protection funds. This method allows the acquisition of information on the functioning of various organizations. The subject matter of the research was the activity of 16 provincial environmental protection and water management funds as well as the National Fund for Environmental Protection and Water Management. Based on a series of 238 observations, the authors analyzed the activities of the fund system in the years 2006-2019. Having conducted a literature review, they decided that a quantifiable and applicable measure to assess the performance of the funds was their administrative efficiency expressed as percentages of resources allocated to the factual support of proposed projects and the functioning of the institutions themselves, respectively. The performed analyses covered the economies of scale and size of granted financial support disaggregated into non-reimbursable aid and reimbursable aid, as well as time series. The research showed a statistically significant relationship between the volume of provided aid and the level of costs (at the significance level of 0.05). The examination of changes in the cost-to-aid ratio in the years 2006-2019 does not provide optimistic conclusions in terms of optimisation of operating costs incurred by individual funds. Funds with relatively low operating costs recorded lower cost increases (in percentage points) than those with high operating costs. The research indicates that there are no mechanisms forcing or motivating the funds to improve their operational efficiency. The operationalization of the relationship between the type of provided aid (reimbursable vs. non-reimbursable) and the level of costs did not show any connection (the function fit measured by the coefficient of determination R2 did not exceed 0.01 ).
\end{abstract}

Keywords: financing of environmental protection, efficiency of public administration, funds

*e-mail: krzysztof.berbeka@uj.edu.pl 


\section{Introduction}

It is not necessary to convince anyone that the problem of efficiency of institutions responsible for financing environmental protection projects is very important for both, the process of ongoing environmental protection, and minimizing risks associated with climate change. What counts is to what extent financial resources flowing into the environmental funds are spent efficiently. In the years 2006-2019, expenditures on fixed assets used for the purposes of environmental protection and water management in Poland ranged from PLN 18 billion to PLN 9 billion [1]. A considerable part of these expenditures was financed by the system of public environmental protection funds. This system consists of the National Fund for Environmental Protection and Water Management and 16 provincial funds, which together contributed from PLN 1.3 billion to PLN 6.2 billion per year, i.e. from $10 \%$ to $33 \%$ of total expenditures for environmental protection purposes ${ }^{1}$. The role of the funds system is underestimated, as these institutions are active participants in the process of redistribution of EU funds. On the basis of these considerations, one can risk a statement that the system of provincial funds has a considerable impact on the scope and pace of investments related to environmental protection in Poland and the country's adjustment to the EU environmental protection requirements.

So far, the literature on environmental funds has focused on the economic and financial issues of their functioning [2-4] or the theoretical and legal aspects related to their activities [5]. There are successful attempts to describe the principles of functioning of commune and district funds [6] and attempts to develop general methods for evaluating the effectiveness of organizations financing ecological projects [7]. There are quite a few publications dealing with institutional efficiency [8-10]. This literature is mainly concerned with the effectiveness of educational institutions as the efficiency of educational systems raises a lot of doubts.

The literature review conducted by the authors indicates that there is a lack of publications on the institutional effectiveness of environmental protection funds. Therefore, the primary objective of this paper is to assess the administrative efficiency of environmental funds in Poland. In order to make this assessment, the authors rely on data collected in the years 2006-2019. This publication is a response to the existing publication gap. It is addressed to policy makers, employees of environmental protection funds and all those involved in developing practical solution of economic and management problems related to environmental protection.

\footnotetext{
${ }^{1}$ The authors' own work based on the data from [2].
}

\section{Literature Review}

Mitigating climate change requires a transition to low-carbon energy generation systems [11]. Therefore, the literature on the subject increasingly discusses efficiency in the context of environmental improvement [12].

In a simple normative sense, "efficiency means the relationship between achieved results and used resources. Effectiveness, on the other hand, is the extent to which planned actions have been performed and planned results have been achieved" [13].

In publications on environmental protection issues, the concepts of efficiency and effectiveness often appear together and concern various aspects of cost optimization and results improvement. Managers very often refer to improving the effectiveness and efficiency of conducted processes [14] or the efficiency of applying management concepts focusing on quality improvement [15]. The notion of effectiveness is close to the notion of efficiency; one of the ways to improve efficiency is a proper allocation of financial resources [16]. Many standards, including standards for environmental management systems, refer to both effectiveness and efficiency of processes and actions aimed at improving quality or protecting the environment $[17,18]$. Therefore, the concepts of effectiveness and efficiency are the subject of research on environmental management standards [19, 20]. As already mentioned above, the literature on the subject refers to environmental efficiency [21-23]. In some publications, economic efficiency is often equated with environmental efficiency and includes the cost of $\mathrm{CO}_{2}$ emission reduction [24].

Various, albeit not very numerous, studies use the concept of energy efficiency. Energy efficiency is usually assessed on the basis of data obtained from monitoring equipment [25].

The concepts of efficiency and effectiveness constitute the subject of research on environmental improvement. Discussing efficiency, researchers relatively often refer to costs. One publication, for example, focused on optimizing cost control in the marine emissions environment [26]. Efficiency improvement occurs when operating costs are reduced [27].

Effectiveness, on the other hand, is considered as a general concept referring to a degree to which some actions or new resources (e.g. soil additives) produce the expected effect or what has been planned. For example, effectiveness has been the focus of research on the cleansing of soil of hazardous chemicals [28], removal of chemicals from contaminated aquatic environments [29] and fertilizer spraying [30].

Effectiveness has also been addressed by researchers aiming to identify factors that influence trust in scientists dealing with climate change [31]. Effectiveness and efficiency are concepts studied from the point of view of not only functioning environmental 
management systems, but also instruments that stimulate appropriate pro-environmental behaviours such as the rate at which taxes on motor gasoline are passed on to consumers [32].

From an environmental point of view, it is important how to increase operational efficiency and reduce total costs by improving the entire sourcing process and supply chain and not just one organisation [33].

The concept of institutional effectiveness is also variously defined and studied. For example, institutional effectiveness is defined as "the number of executable functions per unit of transaction costs and dysfunction understood as the disorder, non-performance of a certain number of functions arising for various reasons in respect to institutions, agents, systems, as well as individual functions" [8].

It is also often acknowledged that institutional effectiveness can be said to occur when an organisation, through various management methods, improves the quality of its services [9]. In this sense, "institutional effectiveness reflects the extent to which and the quality with which an institution achieves its expectations" [10, 27].

Institutional effectiveness reflects the broad capacity of an institution to perform the tasks to which it is committed [34].

The literature review also covered the methodology of research on institutional effectiveness. It showed a number of different approaches to institutional effectiveness. For example, research focused on educational institutions takes into account the Nine Dimensions of Organisational Effectiveness Instrument [35], the ways in which organisational resources are used (people and financial resources in the context of their planning) [36], resource utilization, graduation rates, success in further course work, pass rates, numbers of licences and certificates, as well customer satisfaction with programmes and services [37]. Environmental research assesses for example countries' progress in implementing technical guidelines and good governance requirements. For the clarity of results, the research process is limited to the three dimensions of effectiveness: ownership of technical methods, administrative capacity and good governance [38]. Researchers develop theoretical models, taking into consideration various functional levels of institutions. For example, the model proposed by Berardo and Gerlak comprises two levels: a broader one related to the existing international agreements (including the principle of reasonable and equitable use of natural resources) and a narrower one related to the functioning of the organisation (e.g. transparency, dissemination of knowledge) [34].

On the other hand, research on the effectiveness of state institutions takes into account the output of the management process (e.g. labour market growth) [39].

One of the dimensions of institutional effectiveness is administrative efficiency defined as "the extent to which a government provides public goods and services with limited resources" [40]. Administrative efficiency is examined in different ways, often based on the assumption that the introduction of improvements such as IT solutions will lead to cost reduction [41]. What is particularly interesting is conditions in which efficiency is achieved, so-called pressure on efficiency [42]. For example, when examining the administrative efficiency of medical organizations, the following criteria are taken into account: insurance costs, hospital administrative costs, doctors' bills and overheads [43].

In this paper, the authors intend to determine the efficiency of environmental protection funds. The first step in the research process was a review of publications on these organizations. The conducted literature review showed that previous publications on environmental protection funds addressed the issues of sources of funding for environmental protection tasks [2-4], theoretical and legal issues of activities of provincial environmental protection funds [5], financing of projects based on funds' resources [44], controversies over the functioning of special purpose funds [6], functioning of commune and district funds [45] and methods of assessing the financial efficiency of special purpose ecological funds [7, 46, 47].

It also indicated a considerable volume of literature on both the effectiveness and efficiency of various organizations. However, there were no publications on the functional efficiency of environmental protection funds.

\section{Method}

The authors started the research with a review of available literature. The literature on the subject was reviewed in the course of the following stages: (1) selecting keywords: (efficiency, effectiveness, environment, institutional effectiveness), (2) searching for works containing the identified keywords in the following databases: Academic Search Ultimate, including Business Source Ultimate, Education Resources Information Center, AGRICOLA, Green FILE, and Google Scholar, (3) becoming familiar with the returned publications, (4) reviewing the publications, (5) preparing a map of the available literature, (6) summarizing the selected publications and (7) arranging the collected research material. The applied procedure is consistent with the general methodology of conducting research [48] and the methodology of research in management sciences.

The basic research method applied in the empirical part was an analysis of data contained in the documentation of environmental protection funds. This method allows the acquisition of information on the functioning of various organizations. The subject matter of the research was the activity of 16 provincial environmental protection and water management funds as well as the National Fund for Environmental Protection and Water Management. 
The system of public funds supporting the activities of businesses, local governments and households in the field of environmental protection is somewhat unique in Europe. Particular countries have institutions providing support for pro-environmental activities, but their scopes of operations are much smaller than that of the environmental funds functioning in Poland. Based on a series of 238 observations, the authors analysed the activities of the fund system in the years 2006-2019. Although provincial environmental protection funds were established as early as 1993 (and the National Fund for Environmental Protection and Water Management even earlier), due to their independence, for a long time their reports were so different from one another that it was practically impossible to compare and analyze them in any meaningful way. The data used in the analysis were derived from the individual provincial funds' annual reports and financial statements, as well as aggregate reports prepared by the National Fund. As the total number of these documents exceeded 240 , they were not included in the bibliography. Otherwise, its volume would have been greater than that of this paper. In the research, the authors adopted the assumption that an analysis of economic effectiveness and efficiency would not provide a proper picture of the functioning of the provincial funds.

It is possible to study the ability to achieve objectives, i.e. effectiveness, when objectives are measurable and when an organisation may influence them (for example, it can plan them). The funds, on the other hand, design their activities in accordance with expected sources and volume of financing, i.e. goals are set with the awareness of existing budgetary constraints.

Economic efficiency should be a primary criterion for assessing the funds. However, while the cost stream is homogeneous and described in monetary terms, the effects of individual projects are not additive: it is difficult to compare and aggregate different projects related to water protection, waste management, air pollution or environmental education ${ }^{2}$. Theoretically, it is possible to examine economic efficiency in similar areas generating comparable effects, but any practical application of this statement would be difficult. Even if an analysis is narrowed down to, for example, air protection, what remains is the problem of comparability among dust, nitrogen oxides, sulphur dioxide in terms of emission reduction. Some effects of emission reduction are generated simultaneously by a single project; consequently, a deeper disaggregation is not possible in practice.

Therefore, a quantifiable and applicable measure for evaluating the funds is their institutional efficiency limited to administrative efficiency. This efficiency

Nevertheless, such attempts are made. The document entitled "The Joint Operational Strategy of the Environmental Protection National Fund and Provincial Funds for the Years 2013-2016 with an Outlook until 2020" established ten measures of ecological efficiency of projects. is an indicator that answers the question of what percentage of the funds' financial resources is spent on administrative procedures and what percentage is allocated for actual project financing. The basic measure of administrative efficiency is the ratio of a given fund's operating costs to the volume of granted aid (both reimbursable and non-reimbursable). Another measure is the share of operating costs in the total amount of disbursed aid (not all costs related to the administration of funds are qualified as operating costs, therefore, this measure is limited - but uses a standard category from financial reporting).

The notion of disbursed aid is understood to comprise the following categories: payments under loan agreements, grants, preferential loan interest subsidies, reimbursement of communes for lost income, transfer of funds to state budgetary units through the state budget's special -purpose reserve.

After making preliminary calculations, the authors formulated two basic research questions.

1. Does efficiency depend on the size of a fund and on the type of provided aid?

2. Are any significant changes in administrative efficiency possible?

Searching for answers to these questions, the authors performed an analysis of so-called economies of scale and volumes of granted aid disaggregated into grants and reimbursable loans as well as an analysis of time series.

An attempt was made to verify the dependence of the efficiency measure on the following explanatory variables: the annual volume of granted aid and the ratio of reimbursable aid to non-reimbursable one. Due to the protractedness of project evaluation and qualification procedures, a variant smoothing individual streams in the form of a 3-year rolling average was also added to the analysis. This method anticipates a discussion whether the amount of granted aid is a correct measure. Administrative load is created by an influx of applications and the necessity to process them, which does not necessarily result in the conclusion of an agreement and the payment of aid. Data describing, on the one hand, submitted applications and, on the other hand, successful applications resulting in the execution of agreements and the payment (or granting) of aid are not provided in the majority of reports prepared by the provincial funds. Among the funds that provide such data (e.g. the Wrocław fund), the differences reach $14 \%$ (this is the percentage of applications that were rejected, withdrawn, or found not to meet the criteria). Additionally, there is a certain shift resulting from the processing of applications submitted, but not processed in the previous year, and analogically: processed in the current year, however, resulting in the execution of an agreement in the following year. 


\section{Empirical Research Results}

\section{The Impact of EU Aid Distributed by the System of Environmental Protection Funds on the Efficiency Index}

The aforementioned involvement of the funds in the handling of EU projects causes an increase in their operating costs through a larger number of employees. As such handling is incidentally identified and quantified in reports, it creates a certain error in the analysis of administrative efficiency. In order to obtain a picture of this phenomenon, the authors analyzed the dynamics of changes in the ratio between the amount of granted aid and the operating costs of the funds' offices in the years 2006-2019. This relationship is presented in Fig. 1. It is difficult to speak of any clear trend here, which may be explained by the highly variable involvement of the funds in the distribution of EU aid. In contrast to other resources handled by the funds, aid measures are characterised by a huge variability of annual flows, which cannot be followed (at least in the short term) by corresponding changes in the provincial funds' personnel.

The observed fluctuations allowed the authors to conclude that a decrease in the volume of distributed EU aid was accompanied by an increase in the ratio of the funds' operating costs to the total amount of aid paid to successful applicants. This increase does not have to be visible in absolute terms; a decrease in the amount of disbursed aid alone suffices to worsen the ratio. The volume of foreign aid provided in the years 2006-2019 was highly changeable and irregular, which can be seen in Fig. 1. Taking the value for the year 2006 as $100 \%$, there were years in the period under analysis when disbursed foreign aid changed from $85 \%$ to $637 \%$ of the base value. Since all projects co-financed from
EU funds require an applicant's own contribution, the amount of domestic resources (provided, among others, by the provincial environmental protection funds) was also subject to sudden fluctuations.

\section{Economies of Scale - Verification}

The research showed a statistically significant relationship between the volume of provided aid and the level of costs (at the significance level of 0.05).

The function fit measured by the coefficient of determination $\mathrm{R}^{2}$ was 0.50 . However, it is difficult to expect a high fit of a cost function described by a single variable. A visualisation of the variable costs of provided aid for the 238 available observations from the period 2006-2019 is shown in Fig. 2.

A slightly better fit is provided by the analysis averaging costs and granted aid for each fund separately from the period 2006-2019. In this way, 17 values were examined (the 16 provincial funds and the National Fund for Environmental Protection and Water Management), for the values from the period under analysis. The model fit was higher, with $\mathrm{R}^{2}=0.71$. The details are shown in Fig. 3.

\section{Optimisation of Operating Costs}

The examination of changes in the cost-to-aid ratio in the years 2006-2019 does not provide optimistic conclusions in terms of optimisation of operating costs incurred by individual funds. A comparison of the costto-aid ratio at the beginning and the end of the period under analysis indicates a rather surprising relation; the funds with relatively low operating costs recorded lower increases in such costs (in percentage points) than those with high costs (Fig. 4).

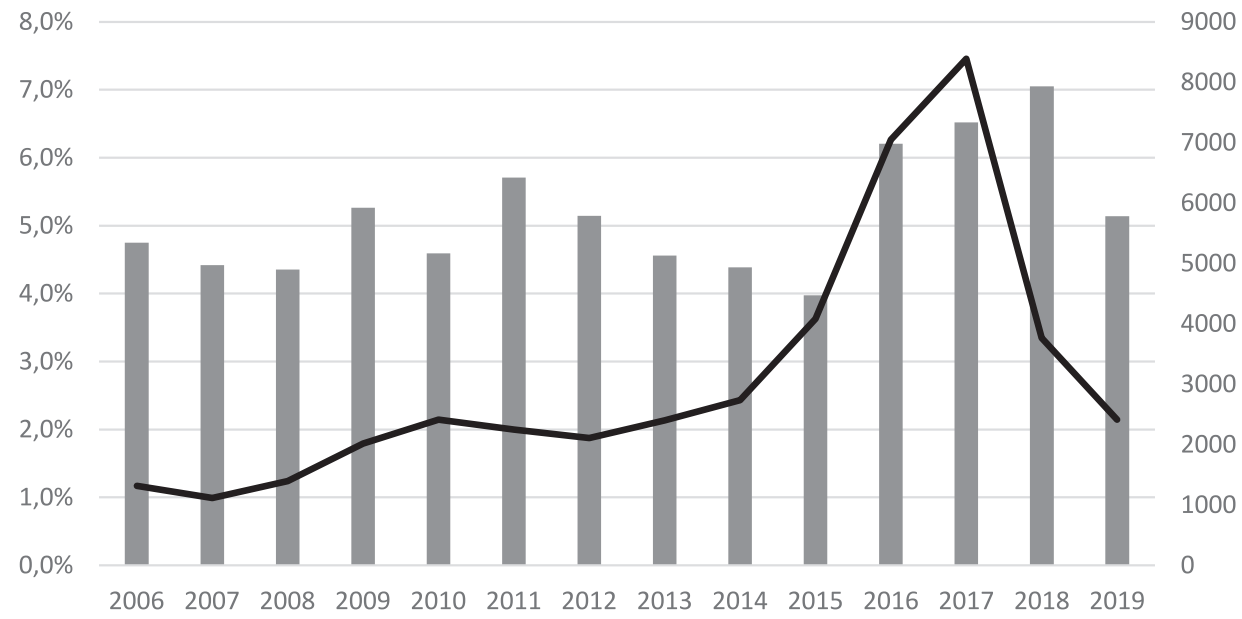

The cost/aid ratio in \% Foreign aid in PLN million

Fig. 1. The ratio of the funds' operating costs to the amount of disbursed aid. Source: The authors' own calculations based on the successive reports of the provincial funds and the National Fund for Environmental Protection and Water Management as well as the data on EU aid presented in the successive Environmental Protection Yearbooks published by the Central Statistical Office. 


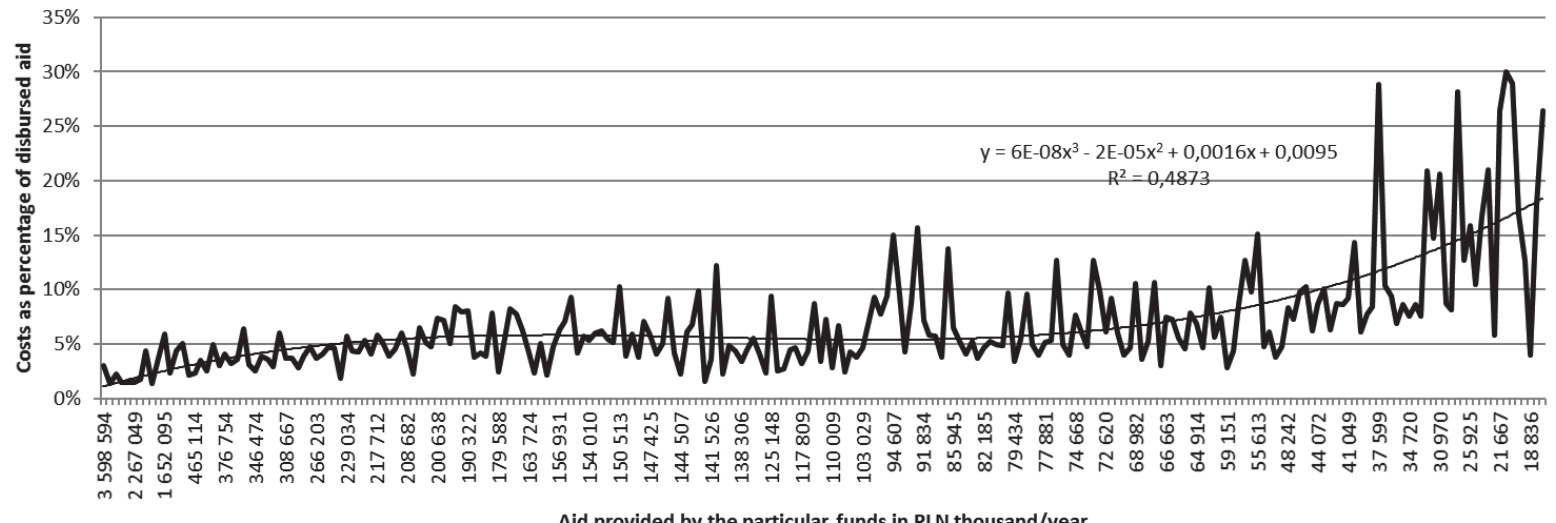

Fig. 2. The variability of the ratio of operating costs to disbursed aid depending on the volume of disbursed aid, for the 16 provincial funds and the National Fund for Environmental Protection and Water Management in the years 2006-2019. Source: the author's own work.

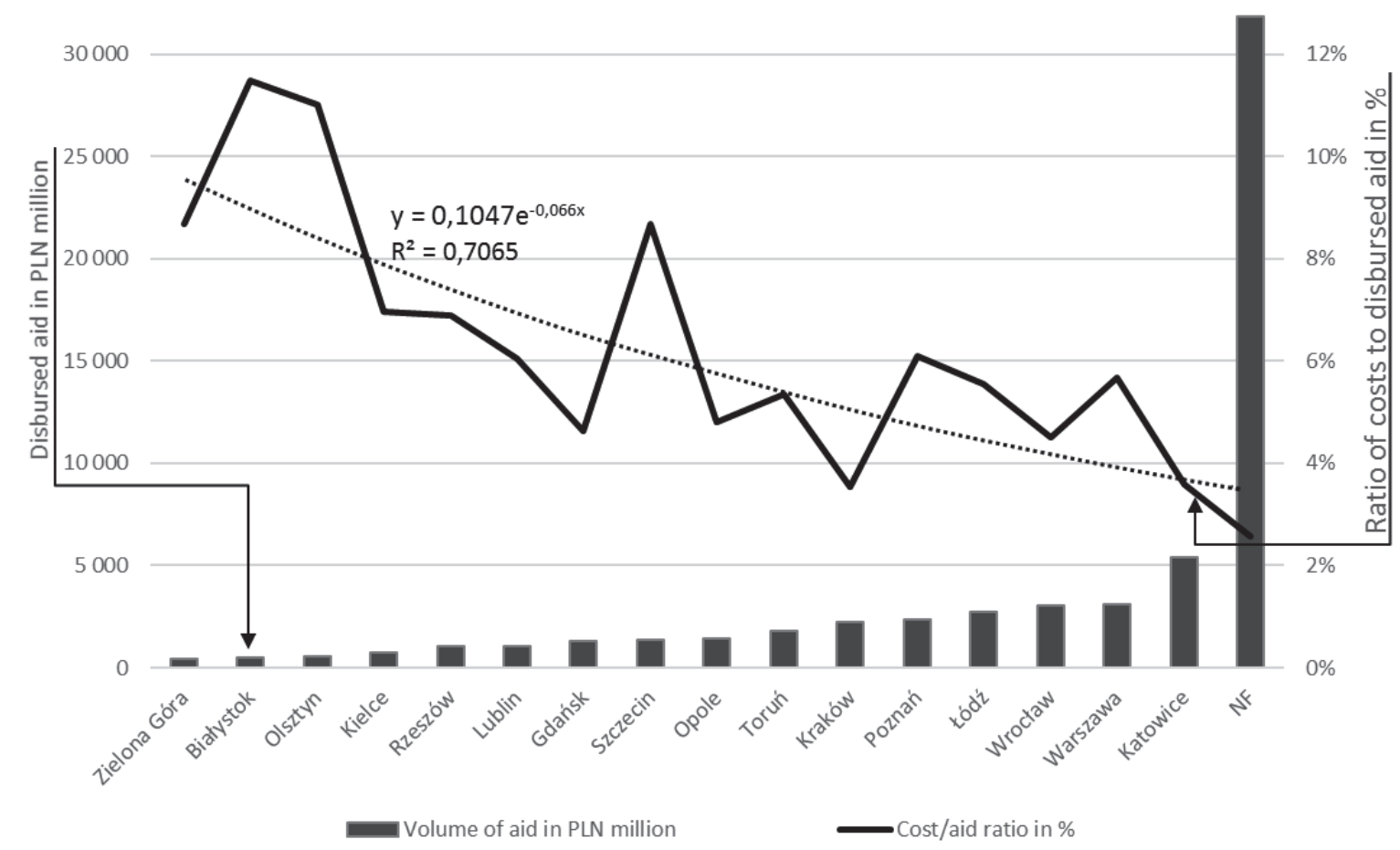

Fig. 3. The variability of the ratio of operating costs to disbursed aid depending on the volume of disbursed aid, for the 16 provincial funds and the National Fund for Environmental Protection and Water Management; the data are averaged for the period 2006-2019. Source: the author's own work.

The described phenomenon indicates the lack of mechanisms forcing the funds to improve their operating efficiency. The funds with the highest operating costs in 2006 (with the exception of the Dolnośląski fund) had higher cost growth dynamics than the most efficient funds.

The examination of the dynamics of increases in both operating costs and disbursed aid did not indicate a relation between these categories. It could be expected intuitively that an increase in the amount of provided aid causes (and justifies) an increase in operating costs. This supposition was not confirmed by the collected empirical data. The changes in the volumes of operating costs and provided aid between the years 2006 and 2019 are presented in Fig. 5.

It should be noted that in the period under analysis the consumer price index (CPI) calculated by means of the chain-link method was about $30.4 \%$ (CPI is a Laspeyres type of index which measures changes in the prices of goods and services bought for 


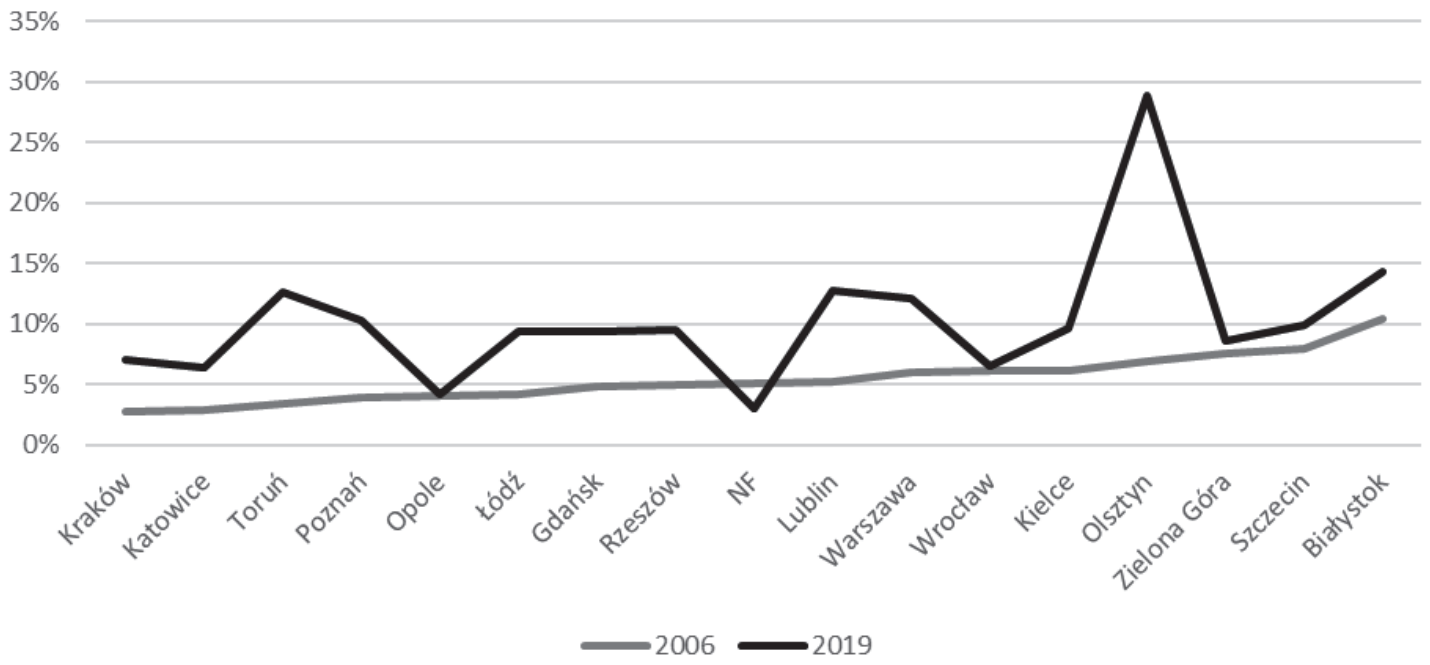

Fig. 4. Changes in the cost-to-aid ratio for the funds under examination between 2006 and 2019.

Source: the author's own work.

consumption purposes by the households, the annual percentage change in a $C P I$ is used as a measure of inflation). On the other hand, the index of changes in the prices of capital expenditures - more adequate for the comparison of the funds' expenditures - was $54 \%$ in the analogous period. The changes observed in the particular funds strongly diverge from the values of both indices mentioned above.

\section{A Type of Disbursed Aid and Its Impact on the Operating Costs of the Funds}

The last test carried out within the scope of the research was checking the relation between the type of provided aid (reimbursable vs. non-reimbursable) and the amount of costs. The operationalisation of this relationship consisted in an attempt to determine the connection between the share of non-reimbursable aid in the total aid and the amount of costs incurred by the individual funds. No relationship was observed in this respect, the function fit measured by the coefficient of determination $\mathrm{R}^{2}$ did not exceed 0.01 .

\section{Discussion}

The research showed a statistically significant relationship between the volume of provided aid and

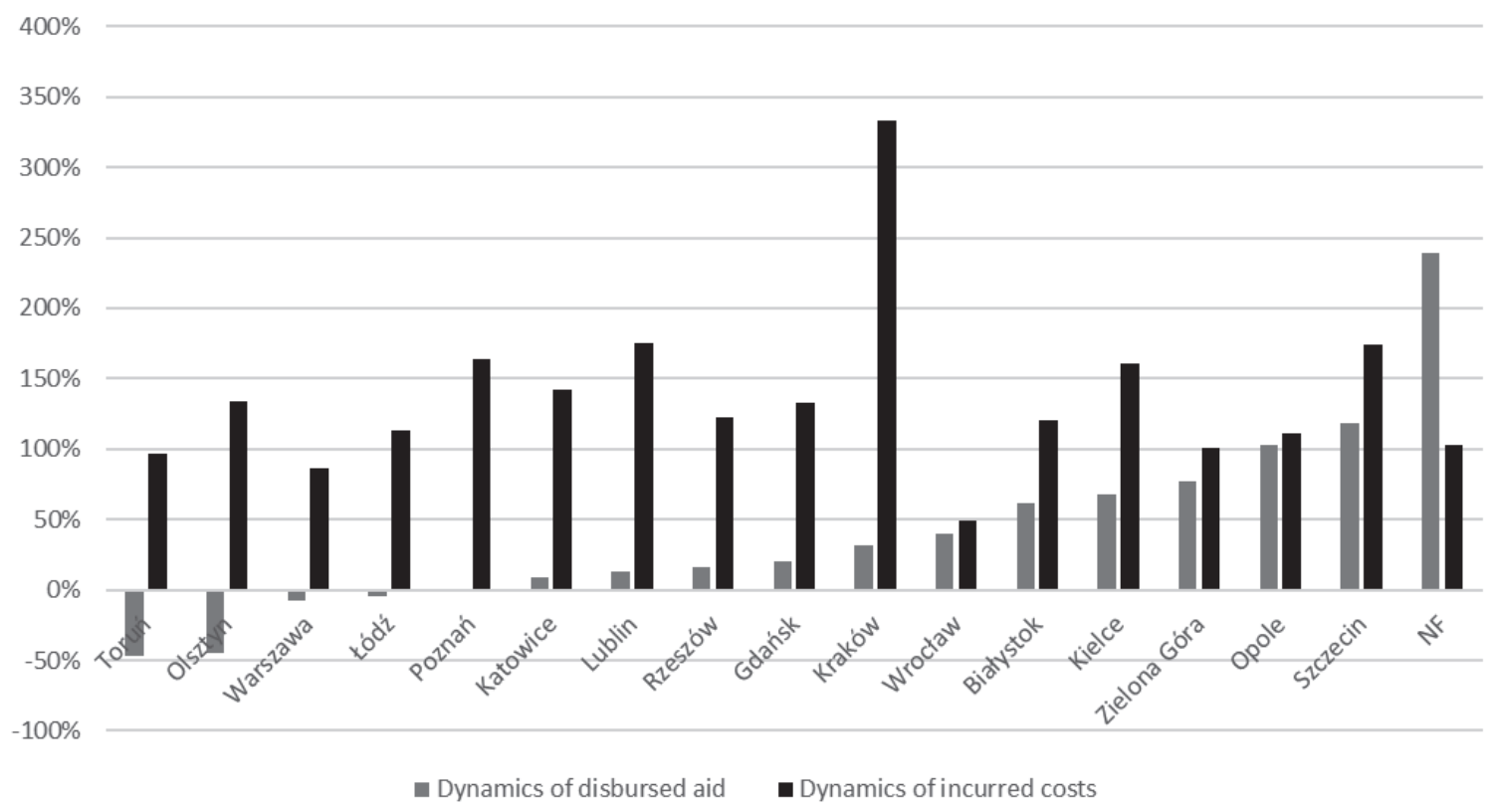

Fig. 5. A comparison between the environmental protection funds' dynamics of incurred operating costs and disbursed aid in the years 2006-2019. Source: the author's own work. 
the level of costs (at the significance level of 0.05). Thus, economies of scale are visible, but they are not an absolute rule. The participation of the funds in the handling of EU projects causes an increase in their operating costs through a larger number of employees. Due to the need to monitor effects achieved by individual projects, the costs associated with this supervision are spread over time far beyond such projects' periods of the financing. Consequently, the funds that are more strongly involved in EU projects experience stronger cost increases. The research also revealed the lack of mechanisms compelling the funds to improve their efficiency. The funds with the highest operating costs in 2006 had higher cost growth dynamics than the group of the most efficient funds. The benchmarking analysis of the funds is of a voluntary nature and does not result in any recommendations or changes.

The analysis of the dynamics of changes in the operating costs of the institutions under examination and the dynamics of distributed aid at the beginning and at the end of the period covered by the research indicates a much faster pace of growth in operating costs than the volume of aid. While the latter depends on the funds' financial resources, which are mostly obtained externally (revenue from environmental fees), the dynamics of incurred costs depends directly on the particular institutions. The growth of costs up to the level of $30 \%$ reflects changes in the consumer price index, but none of the funds recorded such a low rate of increase in operating costs. In 15 cases, the rate exceeded $100 \%$, even in the funds whose volumes of disbursed aid decreased.

Thus, the results of the conducted research indicate the need to take a number of measures aimed at the improvement of management processes. The funds cannot operate on a fire-and-hire basis as this would not be conducive to the quality of either provided services or interpersonal relations. They are also exposed to the temptation of maintaining a huge number of employees, even if they are not needed because there are not enough tasks to fulfil for all of them. Efforts should be oriented towards improving efficiency.

One of the possible measures is an operating model based on lean or reengineering business processes and taking into account the division of processes into repeatable and non-repeatable ones. The funds' existing resources can be adjusted to these processes. Another recommendation is the introduction of management concepts and methods facilitating the improvement of process efficiency, as it is the main component of administrative efficiency. Such concepts include, for example, six sigma, lean or Total Quality Management. The conducted literature review proved that the same approach aimed at efficiency improvement was adopted by educational organizations [35-37].

It also showed a variety of definitions of, and research approaches to, the concept of efficiency. In the case of environmental protection funds, however, it is important to use efficiency measures that take into account the entire length of a so-called quality chain. What is important is not only what happens inside an organisation, but also how decisions on the allocation of available resources affect the improvement of the environment. Therefore, typical environmental effects should be examined. In this sense, the research conducted by the authors confirms the observations and conclusions of other researchers dealing with the operational efficiency of the entire procurement process and supply chain [33].

The setting of environmental objectives should also be approached with caution. Recent reports indicate that so-called numerical targets are not conducive to environmental improvement (e.g. forest monocultures absorb only a fraction of greenhouse gases that could be absorbed by mixed natural forests). Moreover, the lack of progressive systems for allocating financial resources may encourage the practice of establishing purposefully low and easy-toreach objectives.

\section{Conclusions}

The cost of granted aid defined as the cost of the functioning of the Polish environmental protection funds' offices, management boards and supervisory boards in Poland has been systematically increasing. The dynamics of this growth far exceeds the increase of prices in the economy and cannot be justified by significantly larger volumes of disbursed aid.

It was possible to confirm the occurrence of certain economies of scale in the examined sample, but they are not of an absolute nature. The observed economies of scale do not fully justify such a large variation in the funds' operating costs (from 1.3\% to $30 \%$, taking into account the ratio of costs to provided aid).

No relationship was found between the type of aid (reimbursable/non-reimbursable) and the level of costs. For the entire research period from 2006 to 2019, the authors adopted a measure eliminating the impact of price changes and used the ratio between the funds' operating costs and total volume of provided aid. The value of this measure was growing continually during the whole period. The measure was rising faster in the case of the funds with higher operating costs; thus, there was no tendency towards the equalisation of operating costs among the institutions under examination. The analysis of standard deviation for the individual years did not show a decreasing trend. Although the value of the measure was growing, there was no tendency for cost levels to converge. These observations prove the lack of institutionalised mechanisms of cost control in the units as well as the absence of voluntary actions on the part of the funds' management and supervisory boards aimed at efficiency improvement. 


\section{Limitations and Further Research}

There are inherent limitations in the adopted research method. Searches based on keywords and analyses of source texts do not constitute a perfect method as the authors have no possibility to verify the presented results.

A more complete picture of the functioning of the environmental funds and their administrative efficiency could be obtained by conducting research based on a process approach, in which the identification of key processes is followed by an examination of their course within existing organisational structures.

Such an analysis would also be enriched by adding an explanatory variable in the form of the number of executed or handled agreements. It may be assumed that the largest investment projects in the field of environmental protection required under the EU law have already been implemented in Poland. As a result, available aid is divided into a larger number of smaller projects, which increases the costs of their handling. In order to expand the performed analysis, statistical data concerning the number of agreements entered into by the funds with beneficiaries would be required. The funds sporadically publish such information in their reports, but use different and incompatible formats for this purpose. Equally random and sporadic is the provision of information on the average annual number of full-time equivalents (another potential explanatory variable). At the current stage of research, it is therefore not possible to construct a meaningful and complete series of data whose analysis could help to understand such large cost discrepancies.

Due to the cyclical nature of the emergence of tasks related to the handling of EU funds, more meaningful research will be possible by using longer time series and equalized cycles, for examples rolling averages for three years' periods.

Further research could cover the following issues:

- the allocation of resources within the existing key processes,

- the level of an organisation's process maturity,

- the impact of quality management systems on efficiency and effectiveness,

- relations between the level of management turnover and mobility and institutional and administrative efficiency.

Also important are the differences between the funds in the use of different management methods, concepts and systems (a significant number of them assume the necessity of introducing a process approach, which promotes efficiency improvement).

\section{Conflict of Interest}

The authors declare no conflict of interest.

\section{References}

1. Environment. Główny Urząd Statystyczny. Warszawa, kolejne roczniki 2005-2020. https://stat.gov.pl/obszarytematyczne/srodowisko-energia/srodowisko/ochronasrodowiska-2020,1,21.html (Accessed 12.11.2020).

2. KOŻUCH M. Subsidizing the protection of the natural environment in the market economy: Polish experiences. Zeszyty Naukowe - Uniwersytet Ekonomiczny w Krakowie. Seria Specjalna, Monografie. 229, 211, 2013.

3. BARCZAK A., KOWALEWSKA E. Sources of financing of environmental protection tasks in Poland - review of applied solutions. Prawo Budż. Państ. Samorz. 2 (1), 37, 2014.

4. KŁOS L. Sources of financing the environmental protection in Poland. Prace Naukowe Uniwersytetu Ekonomicznego we Wrocławiu. 395, 129, 2015.

5. MARCHEWKA R. Provincial Fund for Environmental Protection and Water Management: administrative and legal issues. Kwartalni Prawa Publicznego. 1-2, 52, 2002.

6. ŁUSZCZYK M. Controversies surrounding the operation of special purpose funds for environmental protection in Poland. Ekonomia i Środowisko. 1, 135, 2006.

7. PIONTEK F. Methodology of assessing the efficiency of spending ecological special purpose funds. Rocznik Ochrony Środowiska. 215, 1999.

8. CУХAPEB O.C. Rule Dysfunction And Institutional Effectiveness. Russ. J Econ. Theory/Zurnal Ekonomiceskoj Teorii. 17 (2), 433, 2020.

9. PHAM N.T.T. Multiple Meta-Assessment Measures of a Quality Process: Toward Institutional Effectiveness. Quality Assurance in Education: An International Perspective. 28 (2), 123, 2020.

10. CLAPP M. Assessing the Efficacy of an Institutional Effectiveness Unit. Assessment Update. 32 (3), 6, 2020.

11. MCPHERSON M., JOHNSON N., STRUBEGGER M. The role of electricity storage and hydrogen technologies in enabling global low-carbon energy transitions. Applied Energy. 216, 649, 2018.

12. NIE Y., ZHANG G. Indicator system to evaluate the effectiveness and efficiency of China clean power systems. Mitig. Adapt. Strat. Gl. 25 (7), 1381, 2020.

13. EN ISO 9000:2015. Quality management systems. Basics and terminology, PKN, Warszawa, 2016. pkt. 3.7.10, 3.7.11.

14. TOOMEY J.W. Adjusting cost management systems to lean manufacturing environments. Production and inventory management journal, 35 (3), 82, 1994.

15. LISOWSKI L.J. Conditions and effectiveness of the application of total quality management (TQM) in construction. Organizacja i Kierowanie, 3, 77, 2004.

16. MOHAMMADFAM I., KAMALINIA M., MOMENI M., GOLMOHAMMADI R., HAMIDI Y., SOLTANIAN A. Developing an integrated decision making approach to assess and promote the effectiveness of occupational health and safety management systems. J Clean. Prod. 127, 119, 2016.

17. ISO 14001:2015, Environmental management system. Requirements and application guidelines, Warszawa, PKN, 2016.

18. PN-EN ISO 9001: 2015, Quality management systems. Requirements, PKN, Warszawa, 2016.

19. ARENA M., AZZONE G., PLATTI M. ISO14001: Motivations and benefits in the Italian metal industry. Int. J Eng. Bus. Manage. 4 (2), 41, 2012. 
20. RAINES S.S. (2003). Perceptions of legitimacy and efficacy in international environmental management standards: The impact of the participation gap. Global Environ. Polit. 3 (3), 47, 2003.

21. MORTAN M., VEREŞ V., BACIU L., RAȚIU P. An Insight on the Romanian Emas Registered Organizations. Managerial Challenges of the Contemporary Society. Proceedings. 11 (1), 11, 2018.

22. MATUSZAK-FLEJSZMAN A., SZYSZKA B., JÓHANNSDÓTTIR L. Effectiveness of EMAS: A case study of Polish organizations registered under EMAS. Environ. Impact Asses. 74, 86, 2019.

23. CORBETT C.J., PAN J.N. Evaluating environmental performance using statistical process control techniques. Eur. J Oper. Res. 139 (1), 68, 2002

24. THAPAR S., SHARMA S., VERMA A. Economic and environmental effectiveness of renewable energy policy instruments: Best practices from India. Renew. Sust. Energ. Rev. 66, 487, 2016.

25. FILIPPIDOU F., NIEBOER N., VISSCHER H. Effectiveness of energy renovations: a reassessment based on actual consumption savings. Energ. Effic. 12 (1), 19, 2019.

26. HAN B., ZHOU Y., PAN X. The Cost Control Optimization Model of Marine Emission Environment Based On Efficiency and Cost Constraint. J Coastal. Res. 115, 469, 2020.

27. MORAN K.A. Organizational resilience: Sustained institutional effectiveness among smaller, private, nonprofit US higher education institutions experiencing organizational decline. Work, 54 (2), 267, 2016.

28. GONZÁLEZ-NÚÑEZ R., RIGOL A., VIDAL M. Assessing the efficacy over time of the addition of industrial by-products to remediate contaminated soils at a pilot-plant scale. Environ. Monit. Assess. 189 (4), 1, 2017.

29. BAIG S.A., WANG Q., WANG Z., ZHU J., LOU Z., SHENG T., XU X. Hexavalent chromium removal from solutions: surface efficacy and characterizations of three iron containing minerals. CLEAN-Soil Air Water, 42 (10), 1409, 2014

30. GARLICH N., GARCIA G.L., DE OLIVEIRA A.C., DOS SANTOS K.P., PITELLI R.A., FERREIRA M.D.C., DA CRUZ C. Electrostatic spraying of imazamox to control the floating aquatic plant Salvinia molesta and its effects on environmental indicators of water quality. J Environ. Sci. Heal. B. 56 (3), 251, 2021.

31. KELLSTEDT P.M., ZAHRAN S., VEDLITZ A. Personal Efficacy, the Information Environment, and Attitudes Toward Global Warming and Climate Change in the United States. Risk Analysis: An International Journal, 28 (1), 113, 2008.

32. KAUFMANN R.K. Pass-through of motor gasoline taxes: Efficiency and efficacy of environmental taxes. Energ. Policy. 125, 207, 2019.
33. JIANG Z. Procurement Management in the Supply Chain Environment: A Practical Guide to Understanding Procurement Management and Enhancing Procurement Effectiveness and Efficiency. Witney, Oxford, UK: Chartridge Books Oxford, 2017.

34. BERARDO R., GERLAK A. Conflict and Cooperation along International Rivers: Crafting a Model of Institutional Effectiveness. Global Environ. Polit. 12 (1), 101, 2012.

35. CAMERON K. An instrument to assess organizational effectiveness in institutions of higher education. 1986.

36. MIDDAUGH M.F. Planning and Assessment in Higher Education: Demonstrating Institutional, San Francisco, Calif.: Jossey-Bass, 2013.

37. ALFRED R.L. The Future of Institutional Effectiveness. New Dir. Commun. Coll. 2011 (153), 2011.

38. OCHIENG R.M., VISSEREN-HAMAKERS I.J., ARTS B., BROCKHAUS M., HEROLD M. Institutional effectiveness of REDD+ MRV: Countries progress in implementing technical guidelines and good governance requirements. Environ. Sci. Policy. 61, 42, 2016.

39. BEER A., LESTER L. Institutional thickness and institutional effectiveness: developing regional indices for policy and practice in Australia. Reg. Stud., Reg. Sci. 2 (1), 205, 2015.

40. STIGLITZ J.E. Economics of the Public Sector ( $3^{\text {rd }}$ ed.), New York: W. W. Norton \& Company, Inc, 2000.

41. PANG M.S., TAFTI A., KRISHNAN M.S. Information Technology and Administrative Efficiency in US State Governments. MIS Quart. 38 (4), 1079, 2014.

42. JEONG Y.C., KIM T.Y. Between Legitimacy and Efficiency: An Institutional Theory of Corporate Giving. Acad. Manage. J. 62 (5), 1583, 2019.

43. WOOLHANDLER S., HIMMELSTEIN D.U. The Deteriorating Administrative Efficiency of the U.S. Health Care System. N Engl. J Med. 324, 1253, 1991.

44. WYCHOWAŁEK K. Financing of ecological education from the resources of voivodship funds for environmental protection and water management, http://krzysztof. wychowalek.pl/pliki/ekofinanse.pdf (Accessed 22.03.2021).

45. HOŁUJ D., HOŁUJ A. Operation of poviat and communal funds for environmental protection and water management. Problemy Ekologii. 8 (1), 13, 2004.

46. ŚWIDERSKI M. Effectiveness of Provincial Funds for Environmental Protection and Water Management, advisor prof. dr hab. Tomasz Żylicz, MSOŚ, 2008.

47. RĄCZKA J., ŻYLICZ T. Public institutions and mechanisms offering concessional funding for mu-nicipal environmental investment in Poland. Agencja Rozwoju Komunalnego, raport dla Ministerstwa Środowiska, Warszawa, 1998.

48. CRASWELL J.W. Designing scientific research. Kraków: Wyd. UJ, 2013 